\title{
The Influence of Green Supply Chain Practices towards Environmental Development: The Malaysian IS014001 Certified Manufacturing Companies Perspective
}

\author{
Marini Nurbanum Mohamad and Charis Samuel Solomon Koilpillai \\ School of Management, Universiti Sains Malaysia, Penang, Malaysia
}

\begin{abstract}
Correspondence should be addressed to: Marini Nurbanum Mohamad; marini_nur@usm.my
Received date: 30 August 2017; Accepted date: 10 December 2017; published date: 13 July 2018

Academic Editor: Tan Booi Chen
\end{abstract}

Copyright (C) 2018. Marini Nurbanum Mohamad and Charis Samuel Solomon Koilpillai. Distributed under Creative Commons CC-BY 4.0

\begin{abstract}
This study examines the influence of green supply chain practices towards environmental development. There has been an increasing interest among scholars concerning the influence of green supply chain practices towards environmental development in the manufacturing industry due to its vast environmental effect and the rising pressure from consumers that companies should 'go green'. A questionnaire was posted to 621 Malaysian ISO 14001 certified manufacturing companies. A total of 146 usable questionnaires were received and the response rate was $23.51 \%$. This study identified that green purchasing and eco-design has a positive effect towards environmental development. These findings provide significant proof of the relationship between green supply chain practices and environmental development. Therefore, the acceptance and application of green supply chain practices in manufacturing firms should be required, not merely based on moral grounds, but also the progressive performance outcomes companies' gain.
\end{abstract}

Keywords: environmental development, green purchasing, eco-design, reverse logistics

\section{Introduction}

In recent years, the issue of sustainability and the environment has become a key managerial concern. Presently, businesses, societies and governments are giving more attention to the issue as there are escalating challenges revolving around balancing between environmental and business requirements. In view of the challenges faced by organisations, green supply chain practices have emerged as an approach that

Cite this Article as: Marini Nurbanum Mohamad and Charis Samuel Solomon Koilpillai (2018)," The Influence of Green Supply Chain Practices towards Environmental Development: The Malaysian IS014001 Certified Manufacturing Companies Perspective ", Journal of Southeast Asian Research, Vol. 2018 (2018),

Article ID 497926, DOI: 10.5171/2018.497926 
extends the environmental responsibility of organizations throughout their entire supply chain. There has been an increasing interest among scholars concerning the influence of green supply chain practices towards corporate sustainable development in the manufacturing industry due to their vast environmental effect and the rising pressure from consumers that companies should go green.

Although green practices are well founded in developed nations, however, they are not well established in developing countries (Gonzales et al., 2010). Little is known about the potential of green supply chain practices towards corporate sustainable development in the Malaysian context. The increasing number of ISO 14001 certification shows that Malaysian corporations aim to endure in the current highly-competitive contemporary business setting (Rahman, 2012). Hence, this paper seeks to investigate the effect of green supply chain practices (green purchasing, eco-design, reverse logistics) towards environmental development.

\section{Literature Review}

\section{Corporate Sustainable Development}

The WCED defined sustainable development as development that meets the requirements of present-days without conceding with the abilities of the forthcoming generations to meet their essentials which are concerning the integration of economic, environmental and social impacts of development (WCED, 1987). There are various viewpoints of analysis in studies on Corporate Sustainable Development (CSD). CSD is recognised as an extensive notion because it comprises of an entire set of normative concerns associated with both the function of businesses in society and the natural setting (Sharma and Ruud 2003).

The main purpose of CSD ought to be for the achievement of a firm's economic performance at the same time considering the societal wellbeing and environmental constraints (Sharma 2002; Osterle et al.,
2010). Yet, the most vital and vigorous debate related to sustainable development is the method and utility of assessment for future needs and desires by an organisation (Saaty, 2008). The requirements of upcoming generations are an attached component of the sustainable development idea (Orlitzky, 2008). Thus, the primary worry to CSD is concerning the decision for forthcoming generations' essentials, where sustainability decisions must have more than a superficial assessment of upcoming necessities, because intergenerational fairness is a difficult, vital and emotional notion that is important for corporate sustainable development dimensions (Yam, 2012).

One of the broadly recognised CSD frameworks explains the paradigms of CSD through three linked dimensions, identified as environmental, economic and social developments (Erol et al., 2009). These three extents of CSD are recognised respectively, environmental development through cooperate environmental management for refining the ecosystem, economic progress through firm value creation by refining the efficiency and effectiveness of services and products, finally, social development through corporate social responsibility in terms of increasing social wellbeing and encouraging better societies (Bansal 2005). This study adopts the works of Chow and Chen (2012) and defines CSD as the extent to which firms are willing to adopt environmental, economic and social development in their operations. This paper presents findings on the effect on environmental development.

\section{Environmental Development}

In general, the complexity in measuring environmental development is evident through the assortment of information utilized, from subjective indications, case studies, and surveys to proprietary information sources (Montabon, Sroufe and Narasimhan, 2007). Numerous researches have resolute to environmental development by utilizing a survey due to its extensive and merely perceptual view (Montabon, Sroufe and Narasimhan, 2007). But countless 
studies have identified a list of items to measure environmental development, such as decreasing water usage (Erol et al. 2009), recycling waste, reversing logistics and redesigning products (Prahinski and Kocabasoglu, 2006) and making green purchases (Diabat and Govindan, 2011).

This study identified the characteristics of present dimensions and measured environmental development from a rather broad and fundamental view. Numerous taxonomies depict environmental development, extending from reactive to proactive advances (Pradeep, 2012). In a majority of cases, the reactive advancement entails activities that could reduce the environmental effect of products and services through proper waste disposal (Schianetz and Kavanagh, 2008). On the other hand, the proactive advancement entails alternate fabrication procedures that reduce waste and emissions (Bansal, 2005). Alternative processes includes, utilizing minimum conventional fuels and reducing negative effects towards animals and the natural environments (Lindgreen et al., 2009). Also, they are practices that reduce procurement of non-renewable resources, chemicals, components and decrease energy utilization (Baumgartner and Ebner, 2010).

\section{Green Supply Chain Practices}

In the $21^{\text {st }}$ century, Green Supply Chain (GSC) has appeared as a significant element of the environmental and supply chain approaches in many companies. GSC practices can be defined as applied organisational activities motivated to allocate and circulate environmental management, in specific progressive environmental managing practices, through the whole supply chain, by extending relationships between large-sized buying organisations and their suppliers (Lee, 2008). In this context, supply chains attempt to preserve internal wellbeing and environmental sustainability by the ability to self-regulate based on data from the external environment (Vachon and Klassen, 2006).
As establishments that form a supply chain become conscious of customer requirements for goods and services delivered without harming the environment, administrators will make choices that support the incorporation and organisation of GSC practices along the supply chain (Vachon and Klassen, 2008). It is commonly thought that supply chains and establishments can achieve competitive advantage by being the pioneers to embrace environmental sustainability and adopt GSC practices (Green et al., 2012). This study adopts the green supply chain practices that were identified by Eltayeb (2009). They conducted a study by reviewing twenty one literatures on green supply chain practices and determined that the green supply chain practices can be categorised into three main practices, namely; (1) green purchasing, (2) eco-design and (3) reverse logistics.

\section{Green Purchasing}

Green products purchasing is one of the responses towards addressing environmental concerns. As green goods are somewhat new for Malaysian industries, there are limited recognized studies about green consumers, green marketing and green product in Malaysia (Shahnaei, 2012). Previous literatures in Malaysian identified cost reductions, marketing prospects and financial earnings from the trade of green goods, to be the key reasons organisations are implementing green practices (Eltayeb, Zailani and Jayaraman, 2009). Currently, companies are gradually dealing with their environmental performance to ensure the supplies and machinery utilized by them are environmentally-friendly and are fashioned from environmentally-friendly procedures.

Largely, green purchasing concentrates on assisting organisations attain savings in the long run by keeping them from any possible losses to their brand value (Shi et al., 2012). In a wider context, green purchasing guarantees the commitment of supply chain managers towards sustainable development by obtaining or purchasing environmental friendly inputs to address the general 
environmental concerns (Kumar et al., 2009). Subsequently, when the virtuous of the company overlaps with the benefit of the society in which it functions, there is a synergistic consequence. Therefore, the company would benefit from improved operations management combined with increased sales as the society shifts toward sustainability and consciousness for greener products.

In addition, green purchasing specifically addresses the environmental concerns of manufacturing firms and is intended to significantly influence environmental management (Diabat and Govindan, 2011). Also, a study by Green et al. (2012) identified that green purchasing provides enhanced economic and environmental management, this leads to enriched operating and organizational outcomes. Owing to this, businesses are aiming for green purchasing among their consumers and implementations of environmental management concepts in their manufacturing processes for sustainable development (Hajli and Hajli, 2013).

\section{Eco-Design}

Eco-design includes activities that change the resources and materials utilized throughout the manufacturing procedures to be less harmful and more environmentally friendly. The main purpose of eco-design is to reduce an item's environmental effect throughout its entire life cycle. The eco-design practise assimilates environmental features into the product designing processes, keeping in mind the complete movement of the product in its supply chain (Handfield et al., 2002).

Eco-friendly or ecological design places importance on investment recapture and is identified to positively affect environmental outcomes. This has been proven in a study by Cheng and Shiu (2012) where they identified, in the manufacturing industry, teamwork with retailers and suppliers' resulted in better environmental performance. Therefore, eco-design facilitates corporations to increase environmental performance and to close the supply chain by managing product practicality while decreasing the environmental effects of product life-cycle (Zhu et al., 2008). Hence, environmentally accountable design or eco-design is a crucial GSC practice that assists firms towards realizing their goals such as replacing harmful and hazardous materials with environmentally friendly substances, decreasing resource usage, and increasing organizational obligation towards their products.

Due to standards and consumers' increasing consciousness of environmental concerns, firms must change their daily actions from design to eco-design to remain competitive. According to Lauring and Thomsen (2009), the only manner to enhance corporate sustainable development is to improvise. That is, to move to more sophisticated types such as product differentiation and innovation through eco-design. However, a substantial reduce in environmental effect is not attained by merely including a 'green' limitation but then again environmental effect is reflected from the designing stage.

\section{Reverse Logistics}

The concept of reverse logistics has been discussed in many past literatures and was initially defined as "the function of logistics in product recovery is to decrease resources, reuse, substitute resources, recycle materials, discard waste, restore, remanufacture and amend" (Lee, 2008). This decrease in resources takes account of both the reduction of resources utilized in goods and the reduction of waste and energy attained through the design of environmentallyfriendly goods (Gupta et al., 2013). Previously, when the alternative of decreasing resource has been used extensively, the subsequent intention was to recycle materials, and to reuse discards through reverse logistics. Yet in organizations, reverse logistics was typically the last option employed (Gupta et al., 2013).

Through the changes of time, in the existing business setting, companies are not solely 
competing on a producer to producer basis, but also on supply chain to supply chain basis. Somewhat, the real competitive encounter is between supply chains (Gupta et al., 2013). Hence, establishments globally have started understanding the significance of reverse logistics towards corporate sustainable development. Thus, companies are required to deal with the reverted goods in an efficient fashion to gain consumer's relationship and reduce the related expenses (Yacob et al., 2012). Consequently, the encouraging findings of reverse logistics among businesses through waste management provide hope to commercialize this idea and are increase practical executed. In a quantifiable manner, reverse logistics are beneficial for the enhancement of sustainable development both at the individual businesses and supply chains level (Starostka-Patyk and Grabara, 2010).

\section{Research Design and Methodology}

A survey was sent to 621 Malaysian ISO 14001 certified manufacturing companies from the Federation of Malaysian Manufacturers (FMM) directory 2014 of Malaysian Industries (FMM, 2014). This research was carried out using a 7-point Likert scale for environmental development. The scales are from $1=$ a small extent to $7=a$

Table 1. The table indicates that most organisations $(32.9 \%)$ are from the electrical and electronics industry and the second highest being from the wood and furniture industry at $17.1 \%$. The remaining percentages were distributed between the metal and machinery, chemicals, food and beverage, rubber and plastic, paper, textile large extent. The items were adopted from Chow and Chen (2012). For green purchasing, eco-design and reverse logistics, this study uses a 5-point Likert scale. The scales are from $1=$ not at all to $5=$ very high extent. The items were adopted from Eltayeb (2009).

The questionnaires were e-mailed to the respondents. After three reminder emails, two postal mails and in-person surveys, 146 completed questionnaires were received. With a total of 146 usable questionnaires, the response rate was $23.51 \%$. The response rate is considered adequate, given the low levels of reply from mail and electronic mail surveys (Sekaran and Bougie, 2013) and generally low response rate for this sort of correlational study in Malaysia. The response rate of this study is also recognised to be satisfactory in relation to similar studies in Malaysia, such as Eltayeb (2009) whose research on green supply chain initiatives stated a $23.9 \%$ response rate and Vachon and Klassen (2006) whose research on green supply chain initiatives attained a response rate of $23 \%$.

SPSS (Statistical Package for Social Science) software for Windows release 21.0 was used to analyse the data. The profile of responding firms are shown in and apparels and finally the other industries. From the table, it can also be observed that there are only a few newly started up organisations (5.5\%) and most of the firms are well established and have been functional for more than 15 years (83.6\%). Likewise, most organisations are noticeably large firms with exceeding 250 employees (75.3\%).

\section{Table 1: Profile of Responding Firms}

\begin{tabular}{|l|l|c|c|}
\hline \multicolumn{1}{|c|}{ VARIABLE } & \multicolumn{1}{|c|}{ CATEGORIES } & FREQUENCY & PERCENTAGE \\
\hline INDUSTRY & Electrical \& Electronics & 48 & 32.9 \\
\hline TYPE & Wood \& Furniture & 25 & 17.1 \\
\hline & Metals \& Machinery & 15 & 10.3 \\
\hline & Chemicals & 11 & 7.5 \\
\hline & Food \& Beverage & 8 & 5.5 \\
\hline & Rubber \& Plastic & 3 & 2.1 \\
\hline
\end{tabular}

Marini Nurbanum Mohamad and Charis Samuel Solomon Koilpillai (2018), Journal of Southeast Asian Research, DOI: 10.5171/2018.497926 


\begin{tabular}{|l|l|c|c|}
\hline & Paper & 2 & 1.4 \\
\hline & Textile \& Apparels & 1 & 0.7 \\
\hline & Others & 33 & 22.6 \\
\hline AGE OF FIRM & Less than 5 years & 8 & 5.5 \\
\hline & $5-9$ years & 5 & 3.4 \\
\hline & $10-15$ years & 11 & 7.5 \\
\hline & More than 15 years & 122 & 83.6 \\
\hline NUMBER OF & Less than 100 & 14 & 9.6 \\
\hline EMPLOYEES & $100-250$ & 22 & 15.1 \\
\hline & $251-500$ & 40 & 27.4 \\
\hline & $501-1000$ & 40 & 27.4 \\
\hline & More than 1000 & 30 & 20.5 \\
\hline
\end{tabular}

\section{Results and Discussion}

A study by Chiarini (2013) reported that, components of social influence, environmental concern, green product knowledge, and environmental labeling are significantly related toward green purchase behavior by organizations. Therefore, towards pursuing sustainable development goals and preserving the environment, implementing green purchasing practices in organizations is essential (Su et al., 2008). Thus this study hypothesizes that:

H1. Green purchasing has a positive effect towards environmental development.

This design for "green" is sometimes referred to or defined as design for the environment. Whereby, the purpose of eco-design is to reduce products' environmental effect without causing an undesirable trade-off with other design standards, such as prices and utility for sustainability. Thus, ecodesign emphasises investment recovery and will positively influence the sustainable development of organisations by decreasing the environmental effect of designs (Green et al., 2012). Thus this study hypothesizes that:

Table 2: Multiple Regression Result: Effect of Green Supply Chain Practices on Environmental Development

\begin{tabular}{|l|c|c|c|}
\hline \multirow{2}{*}{ Variables } & \multicolumn{3}{|c|}{ DV: Environmental Development } \\
\cline { 2 - 4 } & Standard Beta & t-value & p-value \\
\hline Green purchasing & $0.215^{*}$ & 2.531 & 0.012 \\
\hline
\end{tabular}

Marini Nurbanum Mohamad and Charis Samuel Solomon Koilpillai (2018), Journal of Southeast Asian Research, DOI: 10.5171/2018.497926
H2. Eco-design has a positive effect towards environmental development.

The concept of reverse logistics has been defined as "the part played by logistics in merchandise returns, decreasing sources, recovering, materials replacement, reuse of materials, waste removal and restoring, mending, and remanufacturing" (Lee, 2008). It is essential for manufacturers to handle the reimbursed merchandises in an optimal manner to improve customer's relationship and reduce the related charges (Yacob et al., 2012). Reverse logistics aids the practical application of sustainable development both at individual business and supply chain levels (Starostka-Patyk and Grabara, 2010). Thus this study hypothesizes that:

H3. Reverse Logistics has a positive effect towards environmental development.

Regression analysis was conducted to test the hypotheses. Results of the regression analysis of green supply chain practices on environmental development are shown in Table 2 


\begin{tabular}{|l|c|c|c|}
\hline Eco-design & $0.264^{* *}$ & 3.070 & 0.003 \\
\hline Reverse logistics & -0.038 & -0.453 & 0.651 \\
\hline F value & $4.476^{* *}$ & & \\
\cline { 1 - 2 }$R^{2}$ & 0.140 & & \\
\cline { 1 - 2 } Adjusted $R^{2}$ & 0.109 & & \\
\cline { 1 - 2 }$R^{2}$ change & 0.127 & & \\
\cline { 1 - 2 } F change & $6.721^{* *}$ & & \\
\hline
\end{tabular}

Significant levels: ${ }^{*} p<0.05,{ }^{* *} p<0.01$

Referring to Table 2, green purchasing $(\beta=$ $0.215, \mathrm{p}<0.05$ ) showed a significant effect on environmental development. By implementing green supply chain practices, firms generally gain a competitive advantage by adapting their internal and external aspects of their firm. In this study, it has been identified that green purchasing does not only provide internal benefits to the firm but also external benefits to their suppliers. In other words, green purchasing practices in firms reflect on their suppliers, besides the focal firm. This view is supported by Rao (2006), where he stated that generally, green purchasing encourages effectiveness and cooperation amongst business partners and their main companies. In addition, green purchasing also has a significant effect on the company's commitment to the society, environmental development, decreasing waste and attaining cost savings.

This study also identified that eco-design $(\beta=$ $0.264, p<0.01$ ) has a significant effect on environmental development. Results from this study identified a significant effect between eco-design and environmental development. Eco-design, in contrary to green purchasing and reverse logistics, is an internally-focused type of green supply chain practice. This means, firms try to improvise the environmental qualities of their goods internally, with some collaboration or interface from external groups, such as suppliers and consumers. Therefore, the impact is directly linked to the internal productivity and gains to the company. A past study by Green Jr et al. (2012) recognized that effective adoption of green supply chain practices like eco-design, would lead to better environmental and social outcomes which includes enhanced operational and organizational productivity. Green Jr et al. (2012) also further stated that eco-design targets to meet the requirements of consumers for eco-friendly products and services fashioned from green design.

The results of this study also identified that there were no significant relationships between reverse logistics towards environmental development. This finding can be explained through the fact that the government does not play the central role of a facilitator to provide structured responsibilities and obligations for the diverse components involved for environmental conservation and a better social living standard. Therefore, firms are not embracing reverse logistics wholly, instead, reverse logistics are viewed as an optional practice in firms. This finding is supported in past literature by Kersten (2008), where most firms do not embrace reverse logistics whole-heartedly because there is no strong government enforcement for reverse logistics to be practiced in all firms. Therefore, the ultimate potential of reverse logistics for the environment, society and the nation is yet to be achieved.

\section{Conclusion}

This study identified that there exists a statistically significant positive effect of green purchasing and eco-design towards environmental development. The findings of this study is supported by past literature by Chiou et al. (2011), where they determined that greening the supply chain within firms lead to noticeable benefits towards the social standpoint, environmental outcomes and 
added advantages to the corporation. Firms with green supply chain practices can position themselves to gain opportunities and influence the effect of environmental development by concentrating on green purchasing and eco-design, in order to meet environmental requirements encouraged by the government. Also in this research, the Natural Resource Based View theory was used to shed light concerning the current business environment and how firms seek to attain competitive advantage by implementing green supply chain practices for competence in forthcoming years. The findings of this research indicate that managers in Malaysian manufacturing companies have to comprehend that green supply chain practices have significant gains, in terms of satisfying the increasing demands of customers for greener products which can be directly reflected on environmental development. In line with this finding, managers in the Malaysian manufacturing industry are encouraged to amplify their implementation of green supply chain practices so as to lead towards corporate sustainable development.

\section{Acknowledgement}

The authors would like to express their appreciation to Universiti Sains Malaysia Research University (RU) Grant (1001/PMGT/816262) for the financial support to carry out this research.

\section{References}

1. Bansal, P. (2005) 'Evolving sustainably: A longitudinal study of corporate sustainable development,' Strategic Management Journal, 26, 197-218.

2. Baumgartner, R. J., and Ebner, D. (2010) 'Corporate sustainability strategies: Sustainability profiles and maturity levels,' Sustainable Development, 18, 76-89.

3. Cheng, C. C. and Shiu, E. C. (2012) 'Validation of a proposed instrument for measuring eco innovation: An implementation perspective,' Technovation, $32,329-344$.

4. Chiarini, A. (2013) 'Designing an environmental sustainable supply chain through ISO 14001 standard,' Management of Environmental Quality, 24(1), 16-33.

5. Chiou, T. Y., Chan, H. K., Lettice, F. and Chung, S. H. (2011) 'The influence of greening the suppliers and green innovation on environmental performance and competitive advantage in Taiwan,' Transportation Research Part E, 47, 822-836.

6. Chow, W. S. and Chen, Y. (2012) 'Corporate sustainable development: Testing a new scale based on the mainland Chinese context,' Journal of Business Ethics, 105, 519533.

7. Diabat, A. and Govindan, K. (2011) 'An analysis of the drivers affecting the implementation of green supply chain management,' Resources Conservation and Recycling, 55(6), 659-667.

8. Eltayeb, T. K. (2009) 'Adoption of green supply chain initiatives by ISO 14001 certified manufacturing firms in Malaysia: Key drivers, outcomes, and moderating effect of relationship orientation,' (Doctoral dissertation). Retrieved from USM Dissertations and Theses database. (Call No. HD38.5. T236 $2009 \mathrm{f} \mathrm{rb}$ )

9. Eltayeb, T. K., Zailani, S. and Jayaraman, K. (2009) 'The examination on the drivers for green purchasing adoption among EMS 14001 certified companies in Malaysia,' Journal of Manufacturing Technology Management, 21(2), 206-225.

10.Erol, I., Caka, N., Erel, D., and Sari, R. (2009) 'Sustainability in the Turkish retailing industry,' Sustainable Development, 17, 4967.

11.Gonzales, J., Sakundarini, N., Ariffin, R. and Taha, Z. (2010) 'Integrated eco-design tools 
for Malaysian automobile industry,' Journal of Advanced Computational Intelligence and Intelligent Informatics, 14(1), 47-59.

12.Green, K. W., Pamela J. Z., Meacham, J. and Bhadauria, V. S. (2012) 'Green supply chain management practices: impact on performance,' Supply Chain Management: An International Journal, 17(3), 290 - 305.

13.Gupta, V., Abidi, N., Bansal, T., and Jain, R. K. (2013) 'Green supply chain management initiatives by IT companies in India,' IUP Journal of Operations Management, 12(2), 624.

14.Hajli, M. and Hajli, M. (2013) 'Organisational development in sport: cocreation of value through social capital,' Industrial and Commercial Training, 45(5), 283-288.

15.Handfield, R. B., Walton, S. V., Sroufe, R. and Melnyk, S. A. (2002) 'Applying environmental criteria to supplier assessment: a study in the application of the analytical hierarchy process,' European Journal of Operational Research, 141(1), 7087.

16.Kersten, W. (2008) 'Global logistics management: Sustainability, Quality and Risks,' Erich Schmidt Verlag GmbH \& Co KG.

17.Kumar, V., Choisne, F., Grosbois, D. and Kumar, U. (2009) 'Impact of TQM on company's performance,' International Journal of Quality \& Reliability Management, 26(1), 23-37.

18.Lauring, J. and Thomsen, C. (2009) 'Collective ideals and practices in sustainable development: managing corporate identity,' Corporate Social Responsibility and Environmental Management, 16, 38-47.

19.Lee, S-Y. (2008) 'Drivers for the participation of small and medium-sized suppliers in green supply chain initiatives,' Supply Chain Management: An International Journal, 13(3), 185-198.
20.Lindgreen, A., Antioco, M., Harness, D., and van der Sloot, R. (2009) 'Purchasing and marketing of social and environmental sustainability for high-tech medical equipment,' Journal of Business Ethics, 85, 445-462.

21.Montabon, F., Sroufe, R. and Narasimhan, R. (2007) 'An examination of corporate reporting, environmental management practices and firm performance,' Journal of Operations Management, 25, 998-1014.

22.Orlitzky, M. (2008) 'Corporate social performance and financial performance: A research synthesis,' In A. Crane, A. McWilliams, D. Matten, J. Moon, D. Siegel, (Eds.), 2008, The Oxford handbook of corporate social responsibility, (112-134). Oxford, UK: Oxford University Press.

23.Osterle, H., Becker, J., Frank, U., Hess, T., Karagiannis, D., Krcmar, H., Loos, P., Mertens, P., Oberweis, A. and Sinz, E. J. (2010) 'Memorandum on design-oriented information systems research,' European Journal of Information Systems, 20(1), 7-10.

24.Pradeep J. (2012) 'Effect of environmental concern and social norms on environmental friendly behavioral intentions,' Business Intelligence Journal. 169-175.

25.Prahinski, C., and Kocabasoglu, C. (2006) 'Empirical research opportunities in reverse supply chains,' Omega, 34(6), 519-532.

26.Rahman, M. N. (2012) 'The effective implementation of global supply chain management in small to medium-sized companies in Malaysia: An empirical study,' International Journal of Management, 29(3), 2.

27.Rao, P. (2006) 'Greening of suppliers/inbound logistics in the South East Asian context,' In Sarkis, J. (Ed.), Greening the supply chain, Chapter 11, Springer, London, 189-204. 
28.Saaty, T. L. and Peniwati, K. (2008) 'Group decision making: drawing out and reconciling differences,' RWS Publication, Pittsburgh, PA.

29.Schianetz, K., and Kavanagh, L. (2008) 'Sustainability indicators for tourism destinations: A complex adaptive systems approach using systemic indicator systems,' Journal of Sustainable Tourism, 16(6), 601628.

30.Shahnaei, S. (2012) 'The relationship between demographic characteristics and green purchasing of Malaysian consumers,' Interdisciplinary Journal of Contemporary Research in Business, 4(3).

31.Sharma, S. (2002) 'What really matters: Research on corporate sustainability?,' In S. Sharma \& M. Starik (Eds.), Research in corporate sustainability: The evolving theory and practice of organizations in the natural environment (1-29). Northampton, MA: Elgar.

32.Sharma, S. and Vredenburg, H. (1998) 'Proactive corporate environmental strategy and the development of competitively valuable organizational capabilities,' Strategic Management Journal, 19(8), 729753.

33.Shi, V. G., Koh, S.C. L., Baldwin, J. and Cucchiella, F. (2012) 'Natural resource based green supply chain management,' Supply Chain Management: An International Journal, 17(1), 54-67.

34.Starostka-Patyk, M., \& Grabara, J. K. (2010) 'Reverse logistics processes in industrial waste management as an element of sustainable development,' Annales Universitatis Apulensis : Series Oeconomica, 12(2), 698-707.

35.Su, Q., Li, Z., Zhang, S. X., Liu, Y. Y. and Dang, J. X. (2008) 'The impacts of quality management practices on business performance: an empirical investigation from
China,' International Journal of Quality \& Reliability Management, 25(8), 809-823.

36.Vachon, S. and Klassen, R. D. (2006) 'Extending green practices across the supply chain: The impact of upstream and downstream integration,' International Journal of Operations \& Production Management, 26(7), 795-821.

37.Vachon, S. and Klassen, R. D. (2008) 'Environmental management and manufacturing performance: the role of collaboration in the supply chain,' International Journal of Production Economics, 111 (2), 299-315.

38.WCED (1987) 'Our Common Future: The Brundtland Report,' Oxford University Press, Oxford.

39.Yacob, P., Makmor, M. F. M., Zin, A. W. B. M., and Aziz, N. S. B. (2012) 'Barriers to reverse logistics practices in Malaysian SMEs,' International Journal of Academic Research in Economics and Management Sciences, 1(5), 204-214.

40.Yam, S. (2012) 'The practice of corporate social responsibility by Malaysian developers,' Property Management, 31(1), 76-91.

41.Zhu, Q., Sarkis, J. and Lai, K.H. (2008) 'Green supply chain management implications for 'closing the loop,' Transport Research Part E, 44(1), 1-18. 